\title{
Using English Songs to Improve Young Learners` Listening Comprehension
}

\author{
Abeer Abou Ali \\ Lebanese Canadian University, Lebanon \\ abeerabouali@yahoo.com
}

\begin{abstract}
The present study investigates the effectiveness of using songs in improving the listening comprehension skills of young learners in primary cycles. To address this issue, an experimental research study was carried out. A total of 80 young learners of English as-a-foreign language (EFL) participated in the study. Data were collected through administering a structured interview with English language teachers, pre-tests and post-tests, and a questionnaire that assesses young learners attitudes towards using songs. The results demonstrate that there are numerous factors that hinder the improvement of young learners`listening comprehension.However, the use of songs helped learners to develop their listening skill.The study concludes that most of the young learners enjoyed and appreciated learning English through listening to songs. Implications for teaching and further research are discussed.
\end{abstract}

Keywords - Foreign language, young learners, listening comprehension, and songs.

\section{INTRODUCTION}

Listening plays a significant role in the lives of people. Of the four major areas of communication skills and language development - listening, speaking, reading, and writing - the one that is the most basic is listening. Children listen and respond to the language before they learn to talk. In first and second language acquisition, listening is the initial stage. According to Sharpe (2001), the promotion of children's speaking and listening skills lies at the heart of effective learning in all subjects of the primary curriculum. In the classroom, students have to listen carefully and attentively to lectures and class discussions to understand and retain the information they have received.

As Demirel (2004) claimed, of all the four language skills, listening skill is the most difficult one to develop. Therefore, special attention and more time should be devoted to the teaching of such a basic skill. However, it seems that listening is not covered adequately in the curriculum even though 55\% of our lives are spent listening (Costa \& Kallick, 2019 cited in Pearse \& Dunwoody, 2013). Pearse and Dunwoody (2013) posit that active listening skills have to be an integral part of the learning environment to help students become lifelong learners.
Songs are appreciated for their linguistic, pedagogical, cultural, and entertaining features. They are precious language learning materials that can be used to teach and develop every aspect of a language.Vernon in Xiao (2013) said that English songs bring energy to the classroom and boost students' confidence. If the students are interested both in material and teaching, they can enjoy listening. Moreover, the many-faceted merits songs possess may enrich and activate our foreign language class. Georgi Lozanov incorporates music into his teaching methodSuggestopedia, for music is instrumental in creating a relaxing and comfortable environment, which can propel language learning (as cited by Larsen-Freeman, 1985).

Stanislawczyk and Yavener in Kuśnierek (2016) stated "Using songs in the classroom believe that songs are advantageous tools and a teacher should take advantage of it during linguistic practice.Besides, Kuśnierek (2016) stated "Song may be used to relax students since for many learning a new language is a new experience".

By using songs, students not only study but also relax their mind. Futon in Arevalo (2010) said that songs can also provide a relaxed lesson. They also can form the basis for many lessons. English songs are a great language pack that bundles a culture, vocabulary, listening, grammar, and several other language skills in just a few poems. It can be 
used for a wide range of English for teaching and learning foreign languages. This also was supported by Shen (2009) "being a combination of music and language, songs have innumerable virtues that deserve our attention. Their richness in culture and themes, their idiomatic and poetic expressions, their therapeutic functions, and so on makes them an impeccable tool for language teaching". So, utilizing songs in the classroom can relax students' minds and bodies and can make them listening more enjoyable.

Tri Listiyaningsih (2017) stated that listening to English songs can improve listening skill because most children enjoy singing songs, which can often be a welcome change from the routine of learning a foreign language. For the teacher, using songs in the classroom can also be a nice break from following a set curriculum. There has been abundant research abroad on the use of songs as an authentic teaching resource in language teaching (Eken, 1996; Maley, 1997; Geoff, 2003), but a paucity of such studies is reported in Lebanon.

\section{STATEMENT OF THE PROBLEM}

English language teaching (ELT) in Lebanese public schools has been for quite a long time following the traditional path of teaching vocabulary and using grammar textbooks, cramming students with a considerable amount of exercises, and then evaluating their accomplishments through consecutive exams. If we cast a close look at the Lebanese public schools that teach English as a foreign language for young learners, we will notice that the teaching curricula do not treat the listening skill as a priority in teaching. In the evaluation of student success, the emphasis is primarily placed on the grammar and reading comprehension skills, and mostly there is no room for evaluating listening comprehension.

The area of using songs to improve listening has not so far received the due attention in Lebanese context. Accordingly, this research aimed to investigate the effectiveness of using songs to enhance young learners listening comprehension at a primary school level. More specifically, the study addressed the following questions:

1) What are the factors that hinder the improvement of young learners` listening comprehension in cycle one?

2) How would listening to English songs improve listening comprehension of young learners in cycle one?

3) What is the attitude of young learners in cycleone towards using English songs to improve their listening comprehension abilities?

\section{LITERATURE REVIEW}

\section{Listening Skills and Young Learners}

Listening is the receptive use of language, and since the goal is to make sense of the speech, the focus is on meaning rather than language (Cameron, 2001). Sarıçoban (1999) stated that listening is the ability to identify and understand what others are saying. For learners, listening is how spoken language becomes input (i.e., it is the first stage of learning a new language). In the classroom, this happens by listening to the teacher, a $\mathrm{CD}$, or other learners. It is the process of interpreting messages - what people say.

Two theories of speech perception portray listeners as having very different roles. In the first view, listeners play a passive role and simply recognize and decode sounds, and in the second view, listeners play an active role and perceive sounds by accessing internal articulation rules to decode speech (Crystal, 1997). Whether speech perception is active or passive, or a combination of both, Phillips (1993) said that listening tasks are extremely important in the primary school setting, providing a rich source of language data from which children begin to build up their ideas of how the foreign language works. This knowledge is a rich source that YLs draw on to produce language.

Linse (2005) also considered the teaching of listening skills as foundational to the development of other language skills. We should, however, be aware that any kind of listening comprehension activity needs to be well guided with clear aims. To this end, Ur (1996) argued that a listening purpose should be provided in the definition of a pre-set task. The definition of a purpose enables the listener to listen selectively for significant information. Providing the students with some idea of what they are going to hear and what they are asked to do with it helps them to succeed in the task; it also raises motivation and interest. The fact that learners are active during the listening, rather than waiting until the end to do something, keeps the learners busy and helps prevent boredom.

From young learners to adult learners, there are ways of including songs into lessons according to the linguistic ability and interests of students. Children are particularly receptive to sound and rhythm, with musical intelligence 
appearing early on their intellectual development (Davies, 2000). Therefore, it is very essential to show how songs can be implemented to enable teachers to improve the listening comprehension of young learners.

\section{Songs and Young Learners}

The most prominent features of songs that reinforce language acquisition include their rhythmic and repetitive nature and the joy that the association between melody and content brings to the learning activity. Children have a keen awareness of rhythm, and they have not yet experienced the anxiety that can accompany learning a second language (Krashen, 1981). Therefore, there are many advantages of using songs in YL ESL/EFL classrooms, the most striking ones are the following.

\section{Songs Are Keys to Primary Practice}

Most primary school teachers generally use songs as a teaching technique, and Cameron, (2001) claimed that the use of songs and rhymes is also important for YLs in foreign language classrooms. Likewise, Johnstone (2002) claimed that teachers of YLs may make an important contribution to children's early language education by introducing their classes to recorded songs. Demirel (2004) made the strongest claim when he argued that the most effective way to teach listening comprehension, pronunciation, and dictation to YLs was through teaching songs.

\section{Songs Create Safe and Natural Classroom}

\section{Ethos}

According to Cullen (1999), songs are significant teaching tools in teaching ESL/EFL because, as most teachers find out, students love listening to music in the language classroom and they often hold strong views about music. This affinity with music makes songs vital tools to create a safe and natural classroom ethos and to overcome feelings of shyness and hesitation on the part of the learners.

Because of their limited attention span, YLs need a variety of activities. YLs are often shy, and they should join in classroom activities when they feel ready rather than when the teacher demands - an opportunity that songs create (Djigunovich\&Vilke; 2000). The learning characteristics of YLs also reveal a need to develop a strong emotional attachment to their teacher. "Listen and Do" songs support this attachment since the students and the teacher are physically involved in doing the same actions; that is, they share a common experience.
The students' education, including language education, is a process in which students should be encouraged to contribute physically, emotionally, and intellectually. This type of learning environment is best achieved when the teacher creates a safe, non-threatening context within which learners can play with language (Sevik, 2012).

\section{Practice}

\section{Songs Provide Opportunities for Repetition and}

Songs provide excellent opportunities for repetition and practice that might otherwise be tedious. Repetition of language is pleasurable — such as repeating choruses, or singing cumulative songs where each verse borrows words from a previous verse (e.g., "The Twelve Days of Christmas"). This repetition, most often accompanied by physical actions, helps to learn and in turn leads to familiarity so that children feel comfortable with the foreign language (Rumley, 1999). Besides, as argued by Sharpe (2001), by singing songs pupils gradually internalize the structures and patterns of the foreign language as well as the specific language items that the teacher wants them to learn.

Use

\section{Songs Provide Opportunities for Real Language}

According to Sharpe (2001), songs provide an occasion for real language use in a fun and enjoyable situation. She claims that singing is a vital part of the life of a young child, inside and outside the school, and incorporating the foreign language into this fundamental activity is another way of normalizing it. Young children readily imitate sounds and often pleasurably associate singing and playing with rhythms and rhymes from an early age.

Schoepp (2001) believed that the three following patterns emerge from the research on why songs are valuable in the ESL/EFL classroom:

a. Affective reasons: A positive attitude and environment enhance language learning. Songs are an enjoyable activity that contributes to a supportive, non-threatening setting with confident and active learners.

b. Cognitive reasons: Songs contribute to fluency and the automatic use of meaningful language structures.

c. Linguistic reasons: In addition to building fluency, songs provide exposure to a wide variety of authentic language that students will eventually face in nonacademic settings. 


\section{How to Teach Songs}

A word of caution is necessary. As language teachers, we should always bear in mind that our main responsibility is to teach the target language. No matter how fun and enjoyable song activities may be for YLs, we should not get carried away by the music and rhythm of songs. Our main responsibility is not to teach singing skills, but to teach the target language.

Therefore, if songs are used ineffectively, they can easily become mere entertainment and pleasurable interruptions in the school day and, in the long term, they result in boredom and lack of interest. There should be a clear reason in the language teacher's mind as to why and how to use a song. Songs can be an effective means of developing young learners' language skills only when they are well integrated into a scheme of work and carefully selected for the cognitive and linguistic needs of pupils (Sevik, 2012).

Kirsch (2008) stated that listening activities should be based on meaningful, appropriate, and authentic texts (e.g., a story, song, or poem) that assist listening and remembering and that match the language and grade level of pupils. Ersöz (2007) suggested that teachers should be careful to choose songs that: contain simple and easily understood lyrics, link with a topic or vocabulary that learners are studying in class, contain repetitive lines, and allow children to easily do actions (to help emphasize meaning).

The purpose of this paper is to highlight how songs and appropriate follow-up activities can be used effectively as a pedagogical tool in Lebanese public schools to support the development of listening comprehension for young learners in cycle one.Therefore, teachers should develop songs into language learning tasks.

\section{METHOD}

\section{Participants}

The participants were young learners from cycleone who came from a public school. Their ages ranged between 7 and 10. This study was performed on 80 young learners from grade 3.The participants were selected and assigned into four different groups according to their results in the pretests. So young learners of different levels were chosen for each section. One hundred percent of the population was Arabs. They were mainly Lebanese with some Syrians who spoke Arabic as their mother tongue.

\section{Research Design}

In this study, the independent variable was the use of English songs while the dependent variable was the listening comprehension which was measured by the difference in the mean scores between pre-tests and post-tests for both groups. To improve young learners' listening comprehension in cycle one, English songs were used.

\section{Instrumentation}

Three instruments were used to collect data to examine the effectiveness of using songs in improving the listening comprehension of young learners in cycleone. They were as follows:

An open-ended semi-structured interview with seven English language teachers to investigate the factors that hinder young learners` listening comprehension skills in cycle one, pre and post-tests for assessing listening comprehension and a questionnaire that reflected students` attitude towards the use of songs.

\section{Procedure}

At the beginning of this study, an open-ended, semistructured interview was conducted with 15 English language teachers to determine the factors that hinder young learners` listening comprehension in public schools. After recognizing the factors that hinder young learners` listening comprehension, the researcher examined the effectiveness of English songs in improving the learners` listening skills. Therefore, she conducted the present study during one semester that lasted from October to December. The independent variable used in this study consisted of two conditions: an experimental condition in which the students practiced listening to English songs and a control condition in which the students practiced listening according to the traditional methods. Both groups had the same number of hours of instruction, which was one period weekly for about fifty minutes. On the first day, the listening pre-tests were administered by the researcher to both control and experimental groups in each class.

The song "Wheels on The Bus" was used as a pre-test for 50 minutes. It was made up of three parts: pre-listening, while-listening, and post-listening. In the first part, the teacher introduced the vocabulary related to the song by using the picture of a bus and asking students some questions. Then, the song lyrics were handed out to the students. In the second part, the song was played three times out of a laptop computer with extra speakers attached. First, it was played without pauses, the second time with pauses, 
and the third time without pauses. Meanwhile, students were asked to fill in the gaps with the missing words from the box. In the post-listening stage, students were asked to answer questions related to pronunciation and creative writing.

After the listening pre-tests were administered to each group on the first day, the training sessions were held for one whole semester. Every week each section from the experimental groups was given one training session, while the subjects in the control groups listened once per week following the traditional listening curriculum with the help of their English language teacher. The subjects in the experimental groups listened to songs with grammar and vocabulary related to the topics in their textbooks. Since the eight English songs were used as supplemental materials to their English textbooks, the instructional time was intermittent. That is, each song was introduced at the end of each lesson. On average, minutes per period were spent practicing various aspects of language skills such as listening, speaking, vocabulary, pronunciation, and grammar.

When the songs were introduced, young learners worked on listening skills and practiced exercises such as gap-fill tasks and unscrambling sentences. Speaking English was practiced by singing songs as well and by doing exercises to improve the participants` pronunciation. In their last session, the young learners in cycle one were post-tested for fifty minutes to evaluate their progress in listening comprehension. The same tests and instructions were used in both stages (pre-tests \& post-tests). Next, the experimental group learners were given a structured questionnaire two weeks after the end of the treatment. The purpose of the questionnaire was to find out about young learners` attitudes towards using songs in improving their listening comprehension. It took the respondents 20 minutes to complete it with the help and instructions of the researcher.

\section{RESULTS}

\section{Data Analysis}

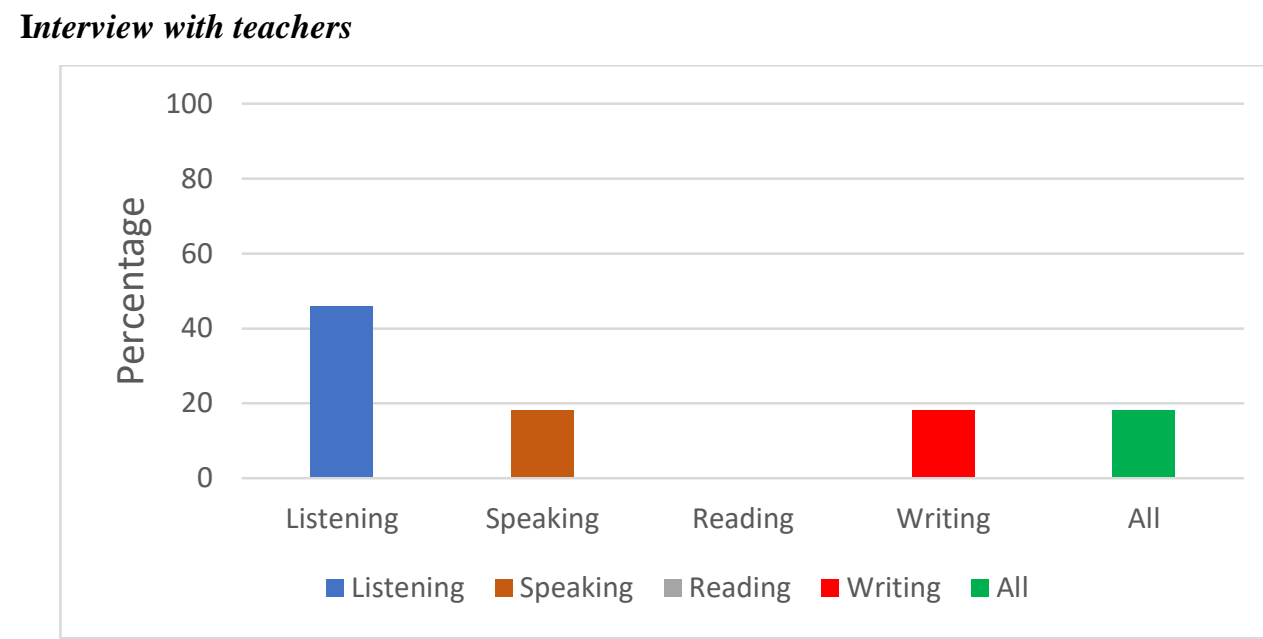

Fig.1: Most difficult skill for young learners. 
International Journal of English Literature and Social Sciences, 5(4)

Jul-Aug 2020 /Available online: https://ijels.com/

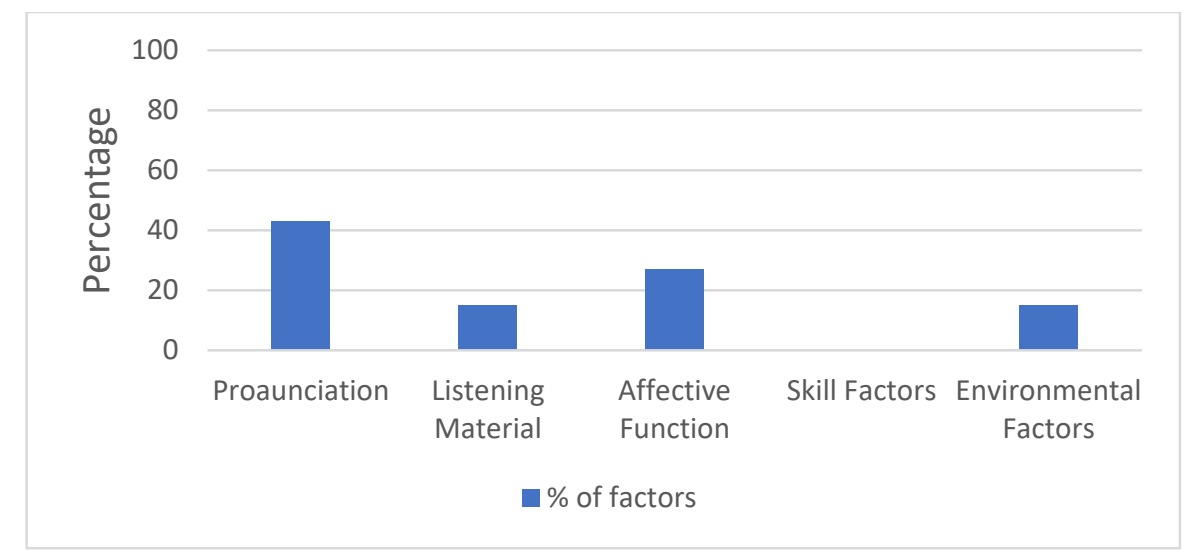

Fig.2: Factors that hinder young learners` understanding of a listening task.

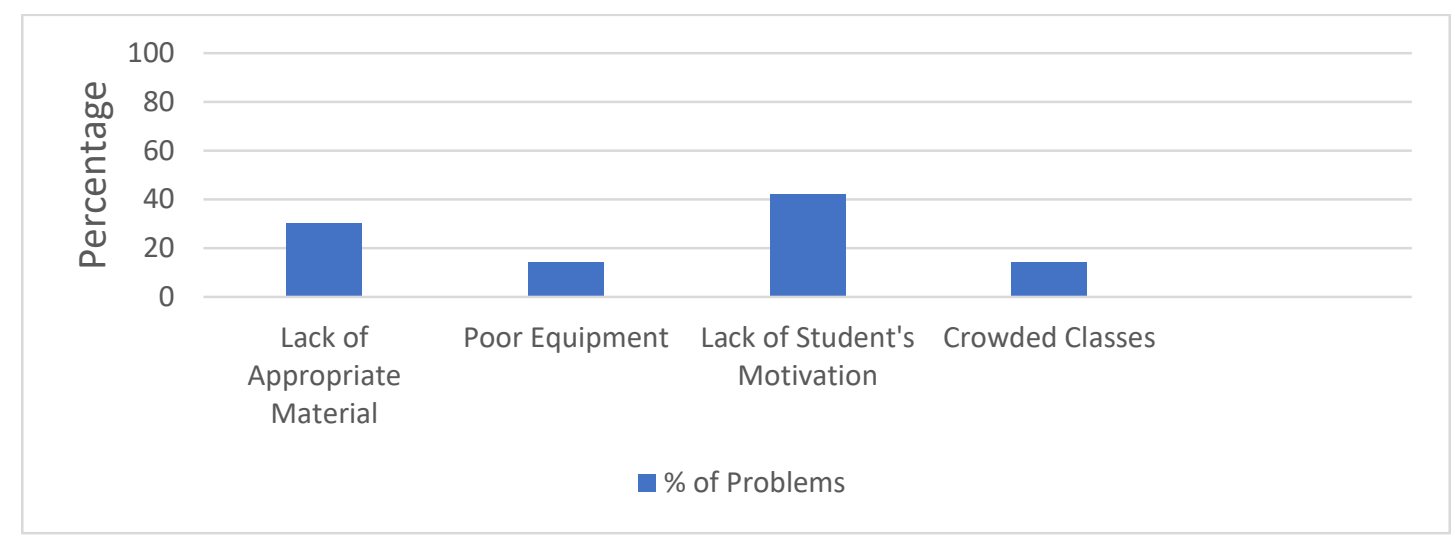

Fig.3: Problems faced by teachers at public schools.

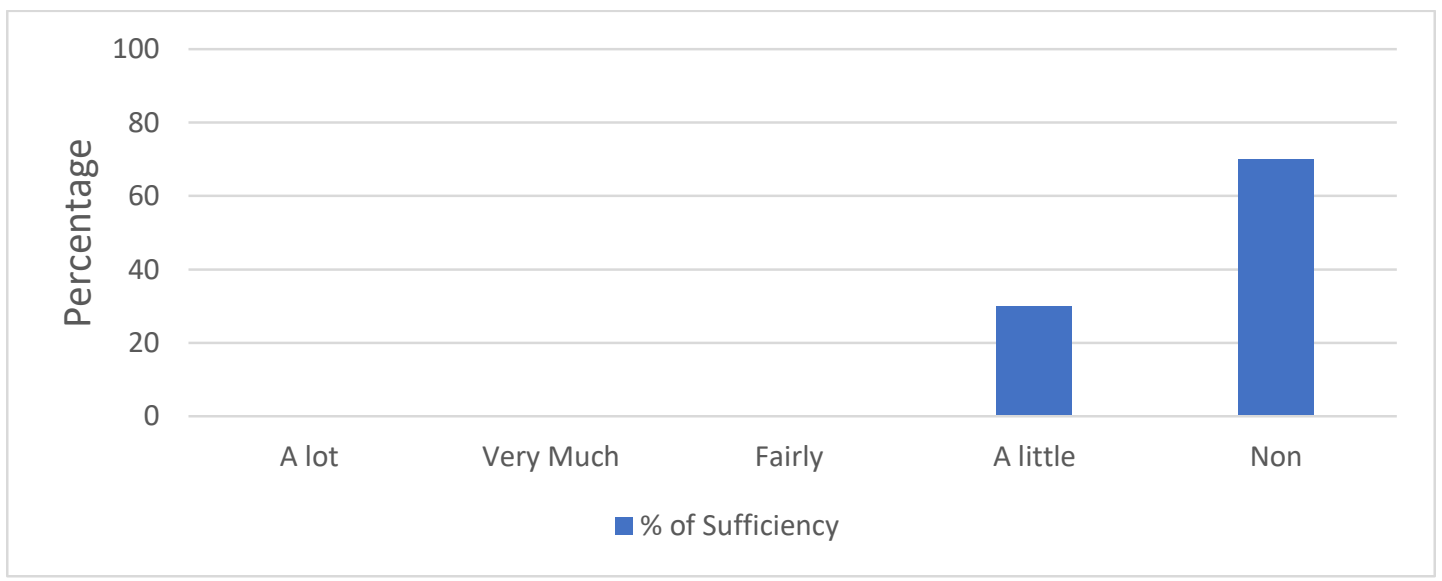

Fig.4: Sufficiency of listening comprehension exercises in textbooks. 
International Journal of English Literature and Social Sciences, 5(4)

Jul-Aug 2020 /Available online: https://ijels.com/

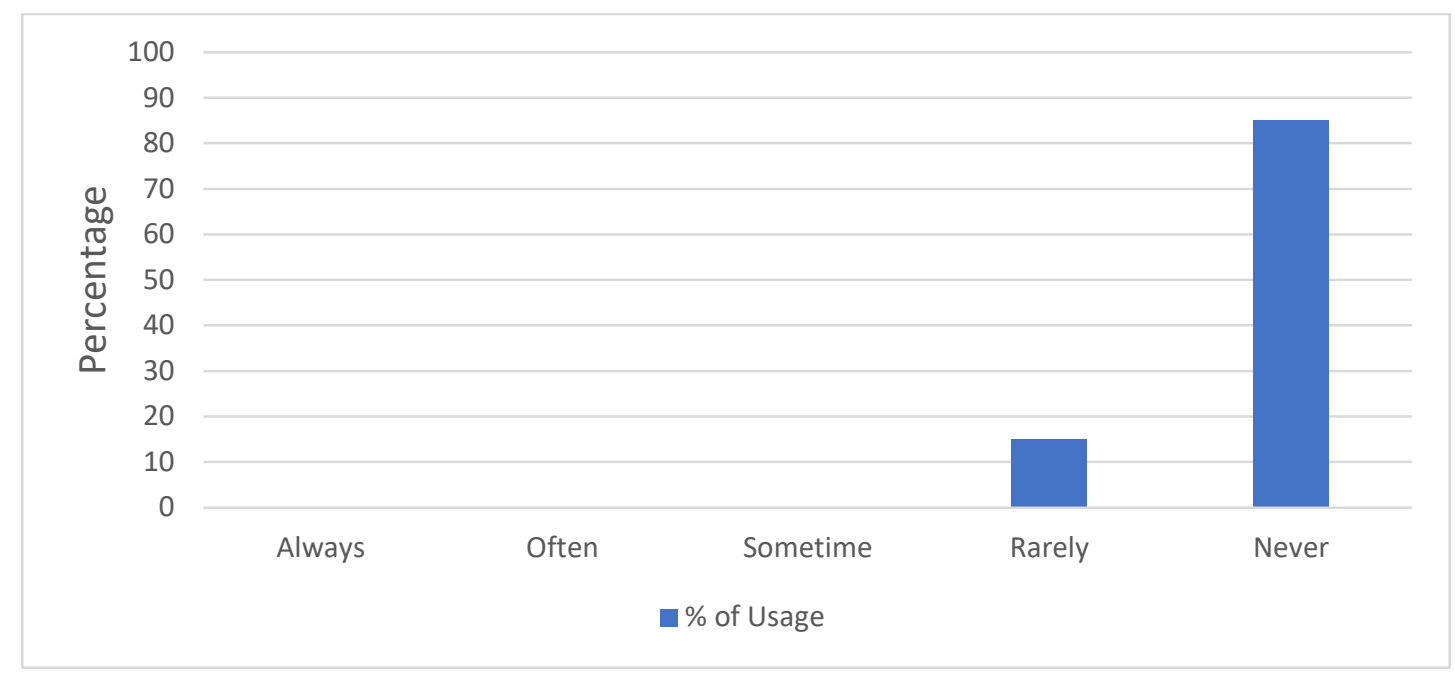

Fig.5: Usage of aural authentic materials by teachers.

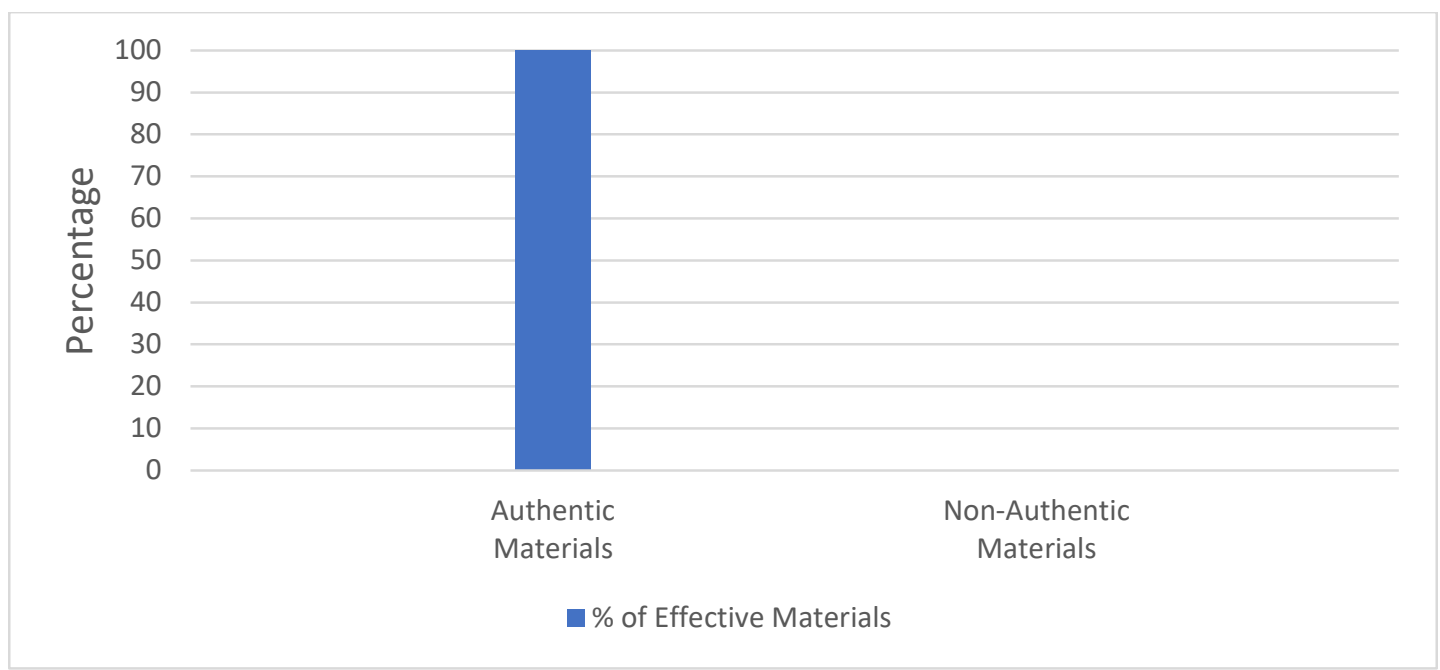

Fig.6: Effective materials in teaching listening comprehension 


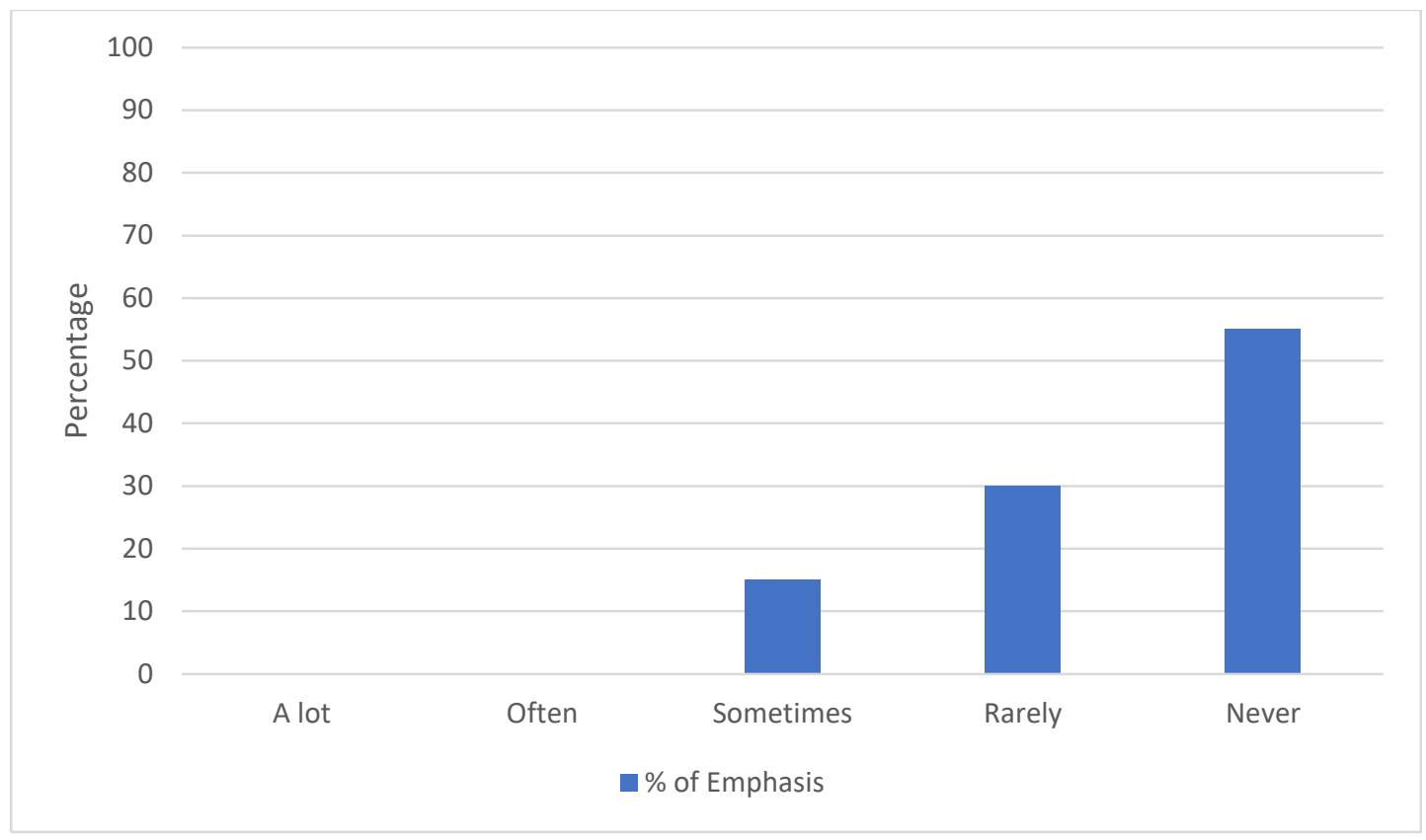

Fig.7: Emphasis on listening skills at public school.

\section{Results of pre-tests and post-tests}

The following table shows the mean and standard deviation in the experimental and control group in pre-test and post-test.

Mean $=$ Average total $=\underline{\text { Sum }(\text { Total grades })}$

number of subjects

The standard deviation can be thought of as measuring how far the data values lie from the mean.

Table 1: Mean M and Standard Deviation SD

\begin{tabular}{ccccc}
\hline & Experimental Group & & \multicolumn{2}{c}{ Control Group } \\
Variables & M & SD & M & SD \\
Pre-test & 1.9 & 0.7 & 2.3 & 0.99 \\
Post-test & 3.6 & 0.8 & 2.4 & 0.95 \\
\hline
\end{tabular}

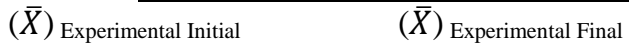

$(\bar{X})$ pre $<(\bar{X})$ post

This means that the average grades of the experimental class after the training sessions are higher than average grades before the experiment. Also, the standard deviation of the pre-test < post-test means that the marks are spread somehow far from the mean, but show improvement in young learners` performance though there is an obvious difference in their performance. 


\section{Questionnaires about Young Learners`Attitude towards Using Songs}

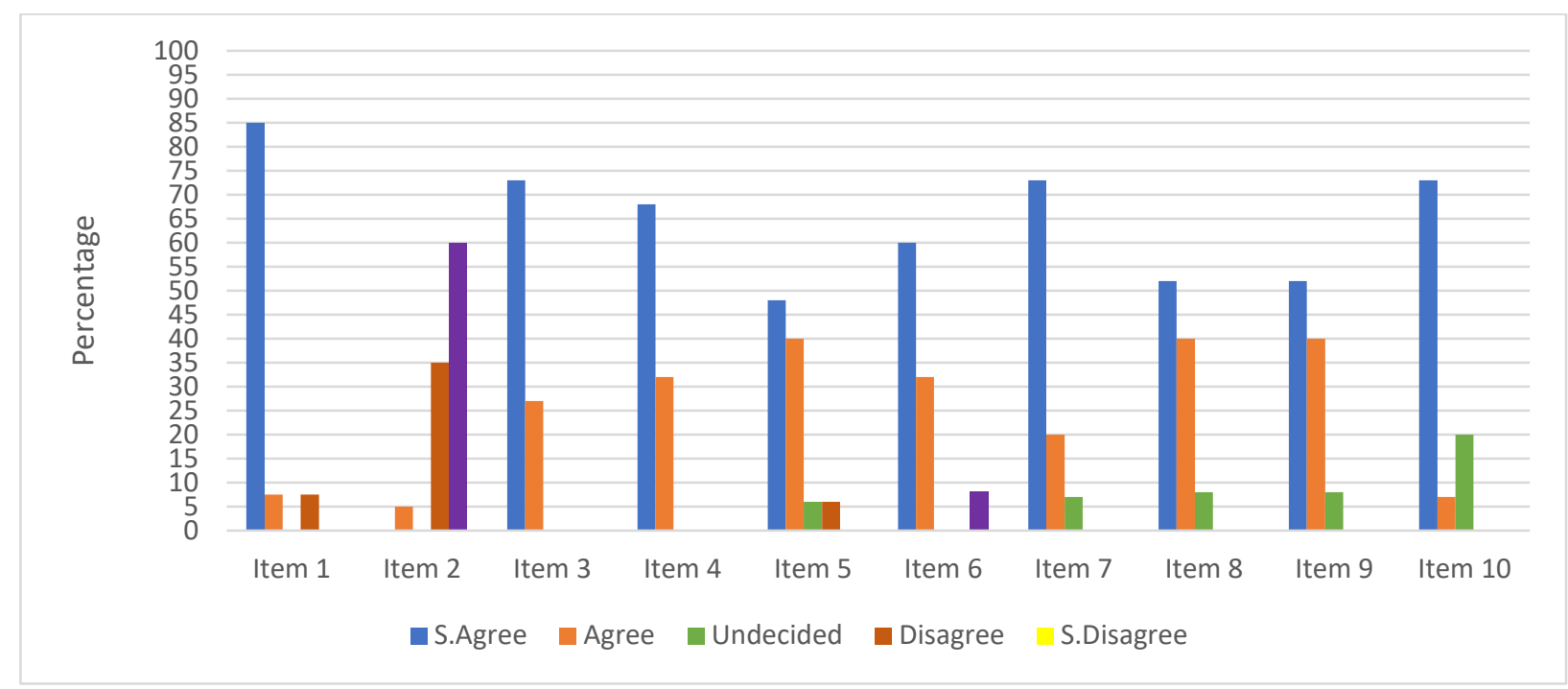

Fig.8: Experimental groups`attitude towards using songs.

\section{DISCUSSION}

This study investigated the effectiveness of using English songs to improve the listening comprehension of young learners in cycle one.The results of the interview conducted with the teachers demonstrated that the listening skill has received only a slight emphasis on teaching English as a foreign language in Lebanese public schools. According to Rost (2002), listening is an important skill for students of second language, and that is why it should be viewed as an integral part of learning and communicating in the target language effectively. Numerous studies indicated that efficient listening skill was more important than other skills as a factor contributing to academic development (Coakley\&Wolvin, 1997). Boyle (1984) indicated the factors that are regarded as the most salient influences on EFL, namely listening comprehension factors that relate to the listener, the speaker, and the materials. This is in agreement with the view of Scarcella and Oxford (1992), who stated that students' anxiety about not understanding anything can lead them to discouragement, fatigue, and a general sense of failure. Moreover, Sharpe (2001) claimed that the promotion of children's speaking and listening skills lies at the heart of effective learning in all subjects of the primary curriculum. Therefore, ESL/ EFL teachers have to consider the development of children`s listening skills as a key aim of primary teaching, so they have to equip children with the best strategies for effective listening. The second research question of this study concerned the role of English songs in improving young learners` listening skills in cycleone.

The results demonstrated that integrating English songs into second language learning classroom activities can have a positive effect on the listening comprehension of young learners, provided that the task given to them is in harmony with their level of proficiency. Comparing the results of the experimental groups with those of control groups, we can see that the use of songs has contributed significantly to the improvement of young learners 'listening skills. This is apparent in the noticeably very good performance of experimental groups in the post-tests. Hence, this result suggests that the experimental groups who listened to English songs had a better performance than the control groups who followed the traditional listening content of the curriculum.

This view is in harmony with Cameron (2001) who demonstrated that the use of songs and rhymes is important for young learners in foreign language classrooms. This is evident in the results of the present study that showed the numerous advantages of teaching songs to young learners in cycleone.According to Djigunovich and Vilke (2000), songs create an opportunity for young learners who often feel shy to join in the classroom activities. This is also in agreement with the view of Cullen (1999) who demonstrated that songs are significant tools in teaching ESL/EFL because students love listening to music in a language classroom environment and they often hold strong views about it. Therefore, the 
results of this study favored the use of English songs as effective tools to enhance young learners` listening comprehension and disapprove of the use of non-authentic materials teaching listening comprehension skills.

Based on the above-mentioned results, the study concluded that most of the young learners enjoyed and appreciated learning English through listening to songs. The findings showed that young learners were extremely motivated to learn English and to enhance their listening abilities. According to young learners` responses, it could be elicited that most of these learners learned how to pronounce words, how to remember a big range of vocabulary, how to practice grammar exercises, and how to write short lyrics and sing songs.

All these observations are following the notions forwarded by Sharpe (2001) who believed that by using songs pupils gradually internalize the structures and patterns of the foreign language as well as the specific language items that the teacher wants them to learn. She also added that songs provide an occasion for real language use in a fun and enjoyable situation.

Besides, Davies (2000) revealed that children are particularly receptive to sound and rhythm, with musical intelligence appearing early on their intellectual development. So, it is very essential to show how songs can be implemented to enable teachers to improve the listening comprehension skills of young learners.

Therefore, the use of songs serves the purpose of improving the listening comprehension skills of young learners in cycle one effectively and efficiently. Songs should be carefully selected to suit the young learners`abilities, and the lyrics should be clear. Finally, it is worth noting that the vocabulary in the songs should be appropriate to the students proficiency level.

\section{CONCLUSION}

The study of the effectiveness of using English songs in improving the listening comprehension of young learners in the primary cycle presented significant results to the Lebanese students and teachers in public schools. The findings of this study could bring to the fore the reasons for considering songs valuable pedagogical tools in teaching listening skills. It is, therefore, concerned in the first instance by highlighting the factors that affect foreign language listening comprehension. It supplies a survey of the most common listening strategies required for improving listening comprehension. The results of this study showed that for these young learners, the use of songs can lead to the attainment of high English language scores.

Consequently, meeting the learning needs of young learners to improve their listening comprehension is a big job, one that requires the coordination and collaboration of the educational system. This means that everyone must support the teaching of listening skills through authentic materials, particularly songs. Furthermore, most of the available practical recommendations are subject to situational constraints: that is they lack universal generalization and application cannot, therefore, be prescribed without adapting them to particular learning situations in which they are to be used. In this paper, the scope of the study was limited only to one foreign language Lebanese public school. The research was restricted to only a small number of subjects and the researcher could only look at the situation of using songs to teach listening to students at a primary level. Hence, the results could not be generalized to all the schools in Lebanon. Moreover, because of limitations in time and space, the researcher did not have enough opportunities to apply the use of songs on a larger scale. The researcher, therefore, hopes that this paper will be a starting point for further study and new applications.

\section{REFERENCES}

[1] Al-Masri, S. Oct. $9^{\text {th }}$ 2017. Personal interview.

[2] Arevalo, E. A. (2010). The Use of Songs as a Tool to Work on Listening and Culture in EFL Class. Cuadernos de Lingüística Hispánica, 124.

[3] Cameron, L. (2001). Teaching languages to young learners:Cambridge University Press.

[4] Costa, A. L., \& Kallick, B. (2014). Dispositions: Reframing teaching and learning. Thousand Oaks, CA: Corwin.

[5] Crystal, D. (1997). The Cambridge encyclopedia of language, $2^{\text {nd }}$ ed. Cambridge: Cambridge University Press.

[6] Cullen, B.(1999). Song Dictation. The Internet TESOL Journal.

[7] Davies, P., and E. Pearse.(2000). Success in English teaching. Oxford: Oxford University Press.

[8] Demirel, Ö. (2004). Teaching modern foreign languages: Language passport, language biography, language dossier. 2nd ed. Ankara, Turkey: Pegem A Publishing.

[9] Djigunovich, J. M., and M. Vilke. (2000). Eight years after: Wishful thinking or the facts of life. In Research into teaching English to young learners, ed. J. Moon and M. Nikolov, 6786. Pécs, Hungary: University of Pécs Press.

[10] Eken, D. (1996). Ideas for using songs in the English language classroom. Forum Journal, 34(1), 46-47. 
[11] Ersöz, A. (2007). Teaching English to young learners. Forum Journal, 22(3), 40-45.

[12] Geoff, P.S. (2003). Music and mondegreens: extracting meaning from noise.ELT Journal 57/2:113-121

[13] Ghazi, S. Oct. $2^{\text {nd }}, 2017$. Personal interview.

[14] Johnstone, R. (2002). Addressing 'the age factor': Some implications for language policy._Strasburg, France: Council of Europe.

[15] Khodor, M. Oct. 7th, 2017. Personal interview.

[16] Kirsch, C.(2008). Teaching foreign languages in the primary school. London: Continuum.

[17] Krashen, S. (1981). Second language acquisition and second language learning. Oxford, UK: Pergamon Press.

[18] Kuśnierek, A. (2016). The Role of Music and Songs in Teaching English Vocabulary to Students. World Scientific News, 43, 24.

[19] Larsen-Freeman, D. (1985). State of the art on input in second language acquisition. In S. Gass\& C. Madden (Eds.), Input in second language acquisition (pp. 433-444). Rowley, MA: Newbury House.

[20] Linse, C. T. (2005). Practical English language teaching: Young learners. New York:

[21] Maley, A. (1997). Poetry and Song as Effective Language learning Activities. In Wigla, M.R. Interactive Language Teaching. CambridgeUniversity Press. Pp.93-109.

[22] Phillips, S. (1993). Young learners. Oxford: Oxford University Press.

[23] Rishani, B. Sept.14 ${ }^{\text {th }}, 2017$. Personal interview.

[24] Rost, M.(2002). Teaching and researching listening. Essex:Pearson Education Limited.

[25] Rumley, G. (1999). Games and songs for teaching modern languages to young children. In The teaching of modern foreign languages in the primary school, ed. P. Driscoll and D. Frost, 114 25. London: Routledge.

[26] Sarıçoban, A. (1999).The teaching of listening. The Internet TESL Journal 5 (12). http://iteslj.org/Articles/SaricobanListening.html

[27] Schoepp, K. (2001). Reasons for using songs in The ESL /EFL classroom. The Internet TESOL Journal[online],7(2),[ Accessed 6 October 2013].

[28] Sevik, M. (2012). Teaching listening skills to young learners through " Listen and Do " songs. English Teaching Forum, 3, pp. $10-16$.

[29] Shen, C.(2009). Using English songs: An enjoyable and effective approach to ELT. English Language Teaching, 2(1) March 2009. Retrieved September 15, 2012. www.ccsent,org.journal.html.

[30] Tyagi, B. (2013). Listening: An Important Skill and Its Various Aspects. The Criterion An International Journal in English, 13.

[31] Ur, P. (1996). A course in language teaching: Practice and theory. Cambridge: Cambridge University.
[32] Xiao, J. (2013). The Function of English Songs to Improve Listening to College English as a Second Language (ESL) Students. University of Wisconsin-Platter.

\section{About the Author}

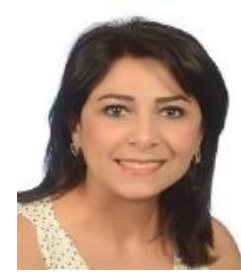

Abeer Abou Ali is an English Language Lecturer at Lebanese Canadian University. She participated in Teaching Excellence and Achievement Program in America in September 2017, during which she developed expertise in her subject area, enhanced her teaching skills and increased her knowledge about the United States. 